\title{
Teaching Basic (Biomedical) Sciences in Nursing Degrees: The Role of Registered Nurses
}

\author{
Fred Saleh* \\ Department of Nursing, College of Public Health, Phoenicia University, Lebanon \\ *Corresponding author: Fred Saleh, Department of Nursing, College of Public Health, Phoenicia University, Lebanon. \\ To Cite This Article: Fred Saleh, Teaching Basic (Biomedical) Sciences in Nursing Degrees: The Role of Registered Nurses. Am J Biomed Sci \& Res. \\ 2019 - 6(4). AJBSR.MS.ID.001043. DOI: 10.34297/AJBSR.2019.06.001043.
}

Received: 眥 October 26, 2019; Published: 些 November 26, 2019

\begin{abstract}
Background and Aim: Basic (Biomedical) Sciences are essential components of undergraduate and graduate Nursing curricula. Faculty members teaching Basic (Biomedical Sciences) in these curricula do not have nursing background and/or qualifications. The aim of this article is to shed the light on the importance of hiring registered nurses with postgraduate qualification in Basic (Biomedical) Sciences to teach in undergraduate and postgraduate Nursing curricula.
\end{abstract}

Method: A detailed systematic search of the various nursing, health, and biomedical databases was conducted. These included PubMed, EMBASE, Medline, Web of Science, PsycINFO, ERIC, and the Cochrane Library. The time interval for the search was from 1970 until 2019. A combination of Mesh terms was used in our search, including Nursing, Nursing Degree, Nursing Curriculum, Contextual Learning, Experiential Learning, Teaching, Subject Expert, Biomedical Sciences, Basic Sciences, Anatomy, Physiology, Embryology, Pathophysiology, Histology, Pharmacology, Biochemistry, Microbiology, Immunology, Statistics.

Results: Our results showed that, except for a few publications describing how some Basic (Biomedical) Science courses are taught in Nursing curricula, there were no publications analyzing the importance of hiring registered nurses with postgraduate qualification in Basic (Biomedical) Sciences to teach in undergraduate and postgraduate Nursing curricula. One publication focused on who teaches science to Nursing students.

Conclusion: This area of research is still new and requires collaboration among Nursing schools to demonstrate the importance of hiring faculty members with dual qualification in Nursing and Basic (Biomedical) Sciences.

\section{Introduction}

Nursing is a profession in which knowledge, attitude, and skills paly equally important roles. The profession has evolved over the years from simple to evidence-based nursing practice. This could not have been achieved without the evolution that took place in Nursing teaching and learning. A Nursing faculty teaching in an undergraduate or postgraduate Nursing program brings with him/ her a wealth of Nursing experience which he/she kas accumulated over the years as a practicing Registered Nurse (RN). This has been particularly true in core Nursing courses, such as MedicalSurgical Nursing, Critical Care Nursing, Community Nursing, Mental Health Nursing, Forensic Nursing, etc. However, foundation Basic (Biomedical) Science courses/subjects are still being taught by faculty members who do not have Nursing background. One major defect related to this practice is that such faculty members are not teaching these courses/subjects within the "context" of the Nursing practice. Accordingly, the other major defect is the inability of these members to judge on what topics should be included in their courses (what is relevant?), the priority of these topics, and how much is enough.

We propose in this paper that Basic (Biomedical) Science courses/subjects in undergraduate and postgraduate Nursing curricula should be taught by RNs who have postgraduate qualifications $(\mathrm{PhD})$ in the field. Such courses/subjects include Anatomy, Physiology, Embryology, Pathophysiology, Histology, Pharmacology, Biochemistry, Microbiology, Immunology, and Statistics. We base our proposal, and, thus, argument on several andragogy theories which will be described in this paper.

Our lives play out in a cyclical pattern, where learning often leads to new experiences and life experiences that are themselves sources of learning. This relationship between experience and learning is particularly prominent in adulthood when we are engaged in a continual flow of activities in the private, public, 
and professional spheres of our daily life. At the heart of adult learning is engaging in, reflecting upon, and making meaning of our experiences, whether these experiences are primarily physical, emotional, cognitive, social, or spiritual. In much of our understanding of adult learning including the foundational work in andragogy, self-directed learning, and transformative learning, an adult's life experiences generate learning as well as act as resources for learning.

It was the philosopher and educator John Dewey and his book "Experience and Education", first published in 1938, who has had the most influence on our understanding of the role of experience in learning [1]. Dewey saw learning as a lifelong process involving applying and adapting previous experience to new situations: "What [one] has learned in the way of knowledge and skill in one situation becomes an instrument of understanding and dealing effectively with the situations which follow. The process goes on as long as life and learning continue" [1]. Several writers have mapped out the relationship between life experience and learning. Experiential learning, initiated by Kolb, represents various conceptualizations of the relationship between experience and learning [2-4]. The term also refers to the use of certain instructional strategies and programs familiar to adult educators that are designed to make learning as authentic and like real-life as possible. Experiential learning is also used to acknowledge an adult's previous life experiences that can be reflected upon and documented for academic credit [2-4]. "Learning," Kolb writes, "is the process whereby knowledge is created through the transformation of experience" [2-4]. Experience is at the heart of his understanding of learning. Kolb's learning model consists of four stages that learners go through in this learning process. These include concrete experience, reflective observation, abstract conceptualization, and active experimentation [2-4].

Learning is best achieved in a context, which is referred as contextual learning. Book knowledge will only get us so far in a complex world of diverse learners and multiple cultures. This is the reason as to why book knowledge has been modified to include contextual balance with practical examples, applications, and resources as a means of connecting theory and practice for the journey of adult learners and educators. Context refers to the social system that shapes the thought and action of people within a setting such as a classroom, school, organization, community, or nation. Context in adult education has been equated with the history and culture of the learner, the setting where adult education takes place, and learning environments [5-10]. The perspective that learning is holistic shifts away from the emphasis on cognitive knowing to acknowledge other ways of knowing such as somatic, spiritual, emotional, moral, experiential, and social learning [1117]. Pratt and Associates discuss five perspectives on teaching that reflect different culturally based beliefs about the instructor's role and responsibilities [18,19].
The five perspectives are:

1) transmission, emphasizing effective delivery of content;

2) apprenticeship, involving modeling ways of being and learning through experience;

3) developmental, cultivating ways of thinking about content, discipline, or practice;

4) nurturing, facilitating self-efficacy, encouraging the learner to build confidence; and

5) social reform, seeking a better society.

By the early 1990s, lifelong learning had supplanted the earlier concept of lifelong education. As Hasan explains, "the word 'education' was replaced by 'learning', to signal an emphasis on the learner, the learning processes and outcomes, as opposed to a focus on imparting education" [20]. UNESCO and OECD took the lead in conceptualizing the concept and "coverage was extended to all purposeful learning activity" across the lifespan, and "learning activities in all settings, from formal education to informal and nonformal learning" [21,22]. Indeed, the notion that lifelong learning should not only be lifelong, from cradle to grave, but "' life wide' recognizing the interplay of informal, non-formal and formal learning in different life domains and 'life deep' incorporating the religious, moral, ethical and social dimensions that shape human expression have led to richer and more pluralistic interpretations of the scope and possibilities of learning throughout the life course" [23].

Learning, Jarvis writes, rarely occurs "in splendid isolation from the world in which the learner lives; it is intimately related to that world and affected by it" [24-26]. All learning takes place in a social context. Learning settings are most often divided into formal, nonformal and informal settings [27]. While this is not a perfect typology and there are instances of overlap and intersection, it is a framework that resonates with most adult learners' and adult educators' experiences. Briefly, formal learning settings are those sponsored by educational institutions, whereas nonformal settings are organized learning opportunities sponsored by institutions, agencies, and community-based groups whose primary mission is other than educational. Informal learning activities are embedded in one's everyday life. If asked about their learning, most adults will refer to a formal classroom situation. Indeed, we have been so conditioned to thinking of learning as something that takes place in an educational institution that our learning at work or in our everyday life does not seem to count as part of our learning. Formal learning sites are equated with educational bureaucracies going from preschool to post-graduate studies. In adult education we would include adult basic education programs, adult high schools, English as a Second Language programs, or professional training programs. We also think of the growing numbers of adults in postsecondary educational institutions. In fact, it has been estimated 
that adults aged twenty-five years and older account for 36\% of students enrolled in four-year colleges and universities [28].

In a provocative article on "post-traditional learners" Soares makes the point that "today traditional students represent only about 15 percent of current undergraduates [29]. Informal learning is by far the most prevalent of the three forms of learning in the Coombs typology. Illeris calls it "everyday learning" because it "takes place in all the private and non-organized contexts of everyday life" [30,31]. Because it is so embedded in our lives, to recognize "everyday learning" as learning we do have to stop and think about it as learning. For example, most of us have encountered a health problem that has sent us to the Internet, the library, and health professionals to learn all we can about this problem, its cause, treatment, and perhaps lifestyle changes required to cope with it. Informal learning often includes several other types of learning. Self-directed learning, an area of research and theory-building in adult education is largely informal, although one can certainly choose to take a class as part of a self-directed learning project. And if one regards self-directed learning projects as a form of informal learning, there is substantial research suggesting that "upwards of 90 percent of adults are engaged in hundreds of hours of informal learning" [13]. Integrative learning may be responsible for creative insight, intuitive leaps, and moments of sudden understanding.

Adult learners possess other roles and responsibilities in addition to their full-time roles as worker, caretaker, and citizen. They could be university or college students, and they often bring along their life experiences into the classroom or lecture hall, a key characteristic of adult learners. Thus, the source of the highest value in adult education is the learner's experience [32]. Kidd wrote "adults have more experiences, adults have different kinds of experiences, and adult experiences are organized differently" [33]. Knowles's andragogy referred to the fact that adults' life experiences not only state who they are as adults, but they also constitute a rich asset for learning [34-39]. Adults are developmentally at different stages in the life cycle, and this has more to do with psychosocial tasks, such as learning to be a parent or a worker [40].

\section{Method}

A detailed systematic search of the various nursing, health, and biomedical databases was conducted. These included PubMed, EMBASE, Medline, Web of Science, PsycINFO, ERIC, and the Cochrane Library. The time interval for the search was from 1970 until 2019. Mesh terms used included Nursing, Biomedical Sciences, Basic Sciences, Anatomy, Physiology, Embryology, Pathophysiology, Histology, Pharmacology, Biochemistry, Microbiology, Immunology, and Statistics.

\section{Results}

Our results showed that, except for a few publications describing how some Basic (Biomedical) Science courses are taught in Nursing curricula, there were no publications analyzing the importance of hiring registered nurses with postgraduate qualification in Basic (Biomedical) Sciences to teach in undergraduate and postgraduate Nursing curricula. One publication focused on who teaches science to Nursing students [41].

\section{Discussion and Conclusion}

There is a lesson to be learned from problem-based learning (PBL). When PBL was implemented in medical curricula, educators argued that the best PBL facilitator is the one who is an expert (for example cardiologist) in the topic being presented in the PBL case (for example heart murmurs), but who does not dominate the PBL group. Accordingly, having a medical background, being a subject expert, and acting as a facilitator are three major characteristics that make up a good PBL tutor. The moral of the story is that medical students are best taught by medical doctors (MDs), engineers are best taught by engineers, and nurses are best taught by RNs. This is because the instructors are subject experts and deliver the information and skills in the "context of the profession" to which they belong. Basic (Biomedical) Science courses are often taught during the first years of a medical or nursing curriculum. However, they are predominantly taught by PhDs in the field who are not MDs or RNs. Our argument in this paper is that the Basic (Biomedical) Science courses offered to nursing students during their undergraduate and postgraduate training should be taught by RNs who have a PhD degree in the field. We supported our argument by examining several theories on andragogy. Adult learning is a key survival skill in an increasingly complex world that is becoming more global, technological, and diverse daily. Learning is crucial to preparing for employment, providing a secure home for loved ones, and participating fully in society. Context is the social system that permeates the thinking and actions of all human beings within a situation such as a classroom, school, organization, community, or nation.

Context may incorporate physical conditions, political conditions, economic conditions, power dynamics, and other influences that impact the people occupying that space. The physical or psychological context may also require its inhabitants to modify their thinking and action when they are occupying the space. Effective learning for adults is cognizant of the intersecting roles the educator, learner, process, and context play in the design and facilitation of learning. The design and facilitation of learning is the bridge between theory and practice in adult education. It is the moment we must take our theories and concepts of adult learning and put them into practice to create relevant, timely, and engaging learning experiences for diverse learners. The connection between experience and learning has been well documented through the years, from Greek philosophers to Dewey and Lindeman [1,32]. Andragogy, self-directed learning, and transformative learning all have life experience as a central component to understanding learning. The most well-known model of experiential learning 
is Kolb's experiential learning cycle [2,3,4]. Adult educators Jarvis, Tennant, and Pogson and Fenwick have all advanced models of experiential learning focusing on adult learners [2426,42-45]. Reflective practice, or practice-based learning, as it is sometimes called, is learning that is acquired through reflection on or in practice (experience). Schön has written extensively about reflection on and in practice, and about espoused theories versus theories in use $[46,47]$. The theory of situated cognition posits that learning is embedded in the context where it occurs, with the tools of that context, and through social interaction. Cognitive apprenticeships and communities of practice enable this form of experiential learning [48].

\section{References}

1. Dewey J (1963) Experience and education. Collier Books, New York, USA.

2. Kolb DA (1984) Experiential learning: Experience as the source of learning and development. Englewood Cliffs, Prentice Hall, USA.

3. Kolb DA, Boyatzis RE, Mainemelis C (1999) Learning Theory: Previous Research and New Directions.

4. Kolb DA, Yeganeh B (2012) Deliberate experiential learning. In: K Elsbach, et al. (Eds), Contemporary Organizational Behavior in Action ( $1^{\text {st }}$ edn). Pearson Education, Upper Saddle River, NJ, USA p. 1-10.

5. Malcolm I (2012) "It's for us to change that": Emotional labor in researching adults' learning: Between Feminist Criticality and complicity in temporary, gendered employment. Adult Education Quarterly 62(3): 252- 271.

6. Malcolm J, Zukas M (2001) Bridging pedagogic gaps: Conceptual discontinuities in higher education. Teaching in Higher Education 6(1): 33-42.

7. Hanson A (1996) The search for a separate theory of adult learning: Does anyone really need andragogy? In: R Edwards, et al. (Eds). Boundaries of adult learning, New York, USA pp. 99-108.

8. Mc Intyre J (2000) Research in adult education and training. In: G Foley (Ed.), Understanding adult education and training. Allen and Unwin, Australia.

9. Alheit P (1999) On a contradictory way to the Learning Society: A critical approach. Studies in the Education of Adults 31(1): 66-82.

10. Field J, Schuller T (1999) Investigating the learning society. Studies in the Education of Adults 31(1): 1-9.

11. Merriam SB (Editor) (2007) Non-Western perspectives on knowing and learning. Malabar, Krieger, Florida, USA.

12. Merriam SB, Brockett RG (2007) The profession and practice of adult education. Jossey Bass, San Francisco, USA

13. Merriam SB, Caffarella RS, Baumgartner LM (2007) Learning in adulthood ( $3^{\text {rd }}$ Edn). Jossey Bass, San Francisco, USA.

14. Merriam SB (2008) Third update on adult learning theory. New Directions for Adult and Continuing Education. No. 199, Jossey Bass, San Francisco, USA

15. Merriam SB, Grace AP (2011) The Jossey Bass reader on contemporary issues in adult education. Jossey Bass, San Francisco, USA.

16. Merriam SB, Kim YS (2011) Non-western perspectives on learning and knowing. In SB Merriam, AP Grace (Eds), The Jossey-Bass reader on contemporary issues in adult education. Jossey Bass, San Francisco, USA pp. 378-389.

17. Trinh MP, Kolb DA (Winter 2011-2012) Eastern experiential learning: Eastern principles for learning wholeness. Career Planning and Adult Development Journal p. 29-43.
18. Pratt DD (1993) Andragogy after twenty-five years. In SB Merriam (Eds), An update on adult learning theory. New Directions for Adult and Continuing Education, No. 57, Jossey Bass, San Francisco, USA p. 15-24.

19. Pratt D (2005) Five perspectives on teaching in adult and higher education. Malabar, Krieger Publishing, USA.

20. Hasan A (2012) Lifelong learning in OECD and developing countries: An interpretation and assessment. In DN Aspin, J Chapman, K Evans, R Bagnall (Eds), Second international handbook of lifelong learning, Part 2. Springer, New York, USA pp. 471-498.

21. UNESCO Institute for Lifelong Learning (2009) Global report on adult learning and education.

22. UNESCO (2008) EFA global monitoring report 2009: Overcoming inequality: why governance matters. Oxford, Oxford University Press, UNESCO Publishing, Paris.

23. Aspin DN, Evans K, Chapman J, Bagnall R (2012) Introduction and overview. In DN Aspin, J Chapman, K Evans, R Bagnall (Eds), Second international handbook of lifelong learning, Part 1. Springer, New York, USA pp. $\mathrm{x} 1 \mathrm{v}-1 \mathrm{x} x \mathrm{x}$ iv.

24. Jarvis P (1987) Adult education in the social context. Croom Helm, London.

25. Jarvis P (2006) Towards a comprehensive theory of human learning. Routledge, London pp. 1-232.

26. Jarvis P (2008) The consumer society: Is there a place for traditional adult education? Convergence, 51(1): 11- 27.

27. Coombs PH, with Prosser RC, Ahmed M (1973) New paths to learning for children and youth. International Council for Educational Development, New York, USA.

28. Sandmann LR (2010) Adults in four-year colleges and universities: Moving from the margin to mainstream? In CK Kasworm, AD Rose, JM Ross Gordon (Eds), Handbook of adult and continuing education. Sage, Thousand Oaks, CA, USA pp. 221-230.

29. Soares L (2013) Post-traditional learners and the transformation of postsecondary education: A manifesto for college leaders. American Council on Education.

30. Illeris K (2004a) Adult education and adult learning. Malabar, Krieger, USA

31. Illeris $\mathrm{K}$ (2004b) The three dimensions of learning. Malabar, Krieger USA.

32. Lindeman EC (1926/1961) The meaning of adult education in the United States. New York, USA.

33. Kidd JR (1973) How adults learn (revised Edn). Association Press, New York, USA.

34. Knowles MS (1968) Andragogy, not pedagogy. Adult Leadership 16(10): $350-352,386$

35. Knowles MS (1970) The modern practice of adult education: Andragogy versus pedagogy. Cambridge Books, New York, USA.

36. Knowles MS (1973) The adult learner: A neglected species. Gulf, Houston, USA.

37. Knowles MS (1977) Self-directed learning: A guide for learners and teachers Malcol m Knowles New York: Association Press, 1975. Group \& Organization Studies 2(2): 256-257.

38. Knowles MS (1980) The modern practice of adult education: From pedagogy to andragogy ( $\left.2^{\text {nd }} e d n\right)$. Cambridge Books, New York, USA.

39. Knowles MS (1984) The adult learner: A neglected species ( $3^{\text {rd }}$ edn). Gulf Publishing, Houston, USA.

40. Erikson E (1963) Childhood and society ( $2^{\text {nd }}$ edn, rev). New York, USA.

41. Naghma Rizvi (2017) Who teaches science to nurses? JPMA 67(7): 1013 
42. Fenwick T (2003) Learning through experience: Troubling orthodoxies and intersecting questions. Malabar, Krieger, USA.

43. Fenwick T (2004) The practice-based learning of educators: A coemergent perspective. Scholar-Practitioner Quarterly 2(4): 43-59.

44. Fenwick T (2008) Workplace learning: Emerging trends and new perspectives. In SB Merriam (editor), Third update on adult learning theory, New Directions for Adult and Continuing Education, No. 119. Jossey Bass, San Francisco, USA p. 17-20.

45. Tennant M, Pogson P (1995) Learning and change in the adult years. Jossey Bass, San Francisco, USA.

46. Schön DA (1983) The reflective practitioner: How professionals think in action. Basic Books, New York, USA.
47. Schön DA (1989) Educating the reflective practitioner. Basic Books, New York, USA 9(2): 115-116.

48. Hu R, Smith JJ (2011) Cultural perspectives on teaching and learning: A collaborative self-study of two professors' first year teaching experiences. Studying Teacher Education 7(1): 19-33. 